University of Nebraska - Lincoln DigitalCommons@University of Nebraska - Lincoln

2013

\title{
Historic Changes (1941-2008) In Side Channel And Backwater Habitats On An Unchannelized Reach Of The Missouri River
}

\author{
L. A. Yager \\ University of South Dakota \\ M. D. Dixon \\ University of South Dakota \\ T. C. Cowman \\ University of South Dakota \\ D. A. Soluk \\ University of South Dakota
}

Follow this and additional works at: http:// digitalcommons.unl.edu/natlpark

Yager, L. A.; Dixon, M. D.; Cowman, T. C.; and Soluk, D. A., "Historic Changes (1941-2008) In Side Channel And Backwater Habitats On An Unchannelized Reach Of The Missouri River" (2013). U.S. National Park Service Publications and Papers. 141. http://digitalcommons.unl.edu/natlpark/141

This Article is brought to you for free and open access by the National Park Service at DigitalCommons@University of Nebraska - Lincoln. It has been accepted for inclusion in U.S. National Park Service Publications and Papers by an authorized administrator of DigitalCommons@University of Nebraska - Lincoln. 


\title{
HISTORIC CHANGES (1941-2008) IN SIDE CHANNEL AND BACKWATER HABITATS ON AN UNCHANNELIZED REACH OF THE MISSOURI RIVER
}

\author{
L. A. YAGER ${ }^{\mathrm{a}, \mathrm{c}}$, M. D. DIXON ${ }^{\mathrm{a}, \mathrm{b} *}$, T. C. COWMAN ${ }^{\mathrm{b}}$ AND D. A. SOLUK ${ }^{\mathrm{a}, \mathrm{b}}$ \\ ${ }^{a}$ Department of Biology, University of South Dakota, Vermillion, South Dakota 57069, USA \\ b Missouri River Institute, University of South Dakota, Vermillion, South Dakota 57069, USA \\ ${ }^{c}$ National Park Service, Missouri National Recreational River, Yankton, South Dakota 57078, USA
}

\begin{abstract}
Flow regulation has had pervasive effects on aquatic ecosystems within the world's large rivers. While channelization on the lower Missouri River has led to major changes in the river and its floodplain, including the loss of shallow water habitats, effects of upstream dams on unchannelized reaches on the Missouri have not been formally assessed. We quantified changes in the number and size of off-channel habitats, specifically backwaters and side channels, on the 95-km unchannelized reach of the Missouri below Gavins Point Dam (Yankton, South Dakota) using historical (1941, 1983-1985, 2008) aerial imagery. Total and mean areas of side channels declined by $77 \%$ and $37 \%$ and total and mean length decreased by $79 \%$ and $42 \%$ from 1941 to 2008 . Total area of backwaters increased by $40 \%$ from 1941 to 2008 , whereas mean area decreased by $36 \%$. Our findings suggest that sharp declines in the area and length of side channels have occurred on this unchannelized remnant reach of the Missouri River, with likely significant impacts on aquatic ecosystem processes. Copyright @ 2011 John Wiley \& Sons, Ltd.
\end{abstract}

KEY WORDS: flow regulation; dams; channel incision; off-channel habitats

Received 2 August 2011; Revised 12 October 2011; Accepted 3 November 2011

\section{INTRODUCTION}

Large river systems around the world have been greatly altered by human actions and no longer exhibit natural functionality (Sparks, 1995; Bayley, 1995; Nilsson et al., 2005). Dams and channelization have disconnected many large floodplain rivers from their floodplains, reducing ecological diversity and function. The effects of these human alterations are widespread; however, cumulative impacts on the health of these large river systems are rarely recognized, and attempts at remediation rarely begun, until significant or irreversible degradation has occurred (NRC, 2002, 2011).

Off-channel shallow water habitats, such as side channels and backwaters, within river floodplains are formed and maintained by river channel migration and avulsion during peak flood events (Shields et al., 2000; NRC, 2002, 2011). These habitats provide many benefits to aquatic ecosystems, including productive spawning and nursery areas for fish (Junk et al., 1989; Price and Townsend, 2004; USACE, 2008; NRC, 2002, 2011), a refuge from high river velocities for aquatic organisms (Sheaffer and Nickum, 1986a; Price

\footnotetext{
*Correspondence to: M. Dixon, Department of Biology, University of South Dakota, Vermillion, South Dakota 57069, USA.

E-mail: Mark.Dixon@usd.edu
}

and Townsend, 2004; USACE, 2008) and warmer water for enhanced temperature diversity within the system (Sheaffer and Nickum, 1986a; USACE, 2008). Off-channel habitats increase inputs of organic matter (both autochthonous and allochthonous) to the river ecosystem and provide productive habitat for aquatic invertebrates (USACE, 2008). Benthos abundance and density are often greater within backwaters (Sheaffer and Nickum, 1986b; Angradi et al., 2006) partially because food (primary and secondary production) is more abundant (Sheaffer and Nickum, 1986a). Loss of these unique areas may reduce both the habitat diversity and the productivity of the river ecosystem (Sheaffer and Nickum, 1986a).

Dams and channelization threaten off-channel habitats by disconnecting the floodplain from dynamic river processes (Ward and Stanford, 1995). Levees and bank stabilization directly restrict dynamic river-floodplain connections (Gergel et al., 2002). Dams reduce overbank flooding and may cause degradation of the channel bed, isolating the river from its floodplain and potentially draining oxbows, backwaters, other floodplain wetlands and side channels (Hesse, 1987; Ligon et al., 1995; NRC, 2011). Reconnection becomes even more difficult as alluvial water tables drop with declining river stage and degrading bed level (Schmulbach et al., 1992; NRC, 2011). Furthermore, dynamic river processes that create new side channels and 
backwaters are reduced by flood control and bank stabilization. These physical changes provide significant challenges for ecological restoration of large rivers in general and off-channel habitats in particular (Weeks et al., 2005).

During the mid-20th century, the Missouri River was greatly modified by construction of six large main stem dams and reservoirs along the upper two-thirds of the river and channelization and stabilization of a navigation channel on the lower third $(1178 \mathrm{~km})$ of the river (Schneiders, 1999; NRC, 2002; Galat et al., 2005). On the lower Missouri, channelization under the Missouri River Bank Stabilization and Navigation Project (MRBSNP) led to major changes in the floodplain and channel, including near complete loss of 'shallow water' littoral habitats such as backwaters and side channels (chutes) within the channelized river (Funk and Robinson, 1974; Whitley and Campbell, 1974; NRC, 2002). Currently, efforts to recreate shallow water habitats are being implemented along portions of the lower, channelized river (Hamburg and Burke, 1999; Jacobson et al., 2004a, 2004b; USACE, 2008). These efforts have largely been driven by mandates under the Endangered Species Act for recovery of the pallid sturgeon (Scaphirhynchus albus) (USFWS, 2000, 2003) and for mitigation of lost habitats. Restoration of shallow water habitat on inter-reservoir and other remnant, unchannelized reaches, however, has not been mandated and remains minimal. Although these reaches retain some natural channel and floodplain features, their flow and sediment regimes have been dramatically altered by upstream dams (Galat and Lipkin, 2000), resulting in disconnection of the floodplain from the channel, reductions in channel meandering and other fluvial geomorphic dynamics and significant degradation of the channel bed (Shields et al., 2000; NRC, 2002, 2011; Galat et al., 2005; Jacobson et al., 2009).

This study assessed historic changes in the number, length, perimeter and area of off-channel habitats, specifically backwaters and side channels, using aerial imagery from pre-dam (1941) and post-dam (1983-1985, 2008) periods within the 59-mile $(95 \mathrm{~km})$ segment of the Missouri National Recreational River (MNRR). This segment is the lowermost unchannelized reach of the Missouri River, running from Gavins Point Dam (the most downstream of the six main stem dams), near Yankton, South Dakota to the beginning of channelization structures near Ponca, Nebraska.

\section{METHODS}

\section{Study area}

The Missouri River (Figure 1) drains approximately onesixth of the conterminous United States, flowing $3768 \mathrm{~km}$ from the Rocky Mountain foothills of eastern Montana,

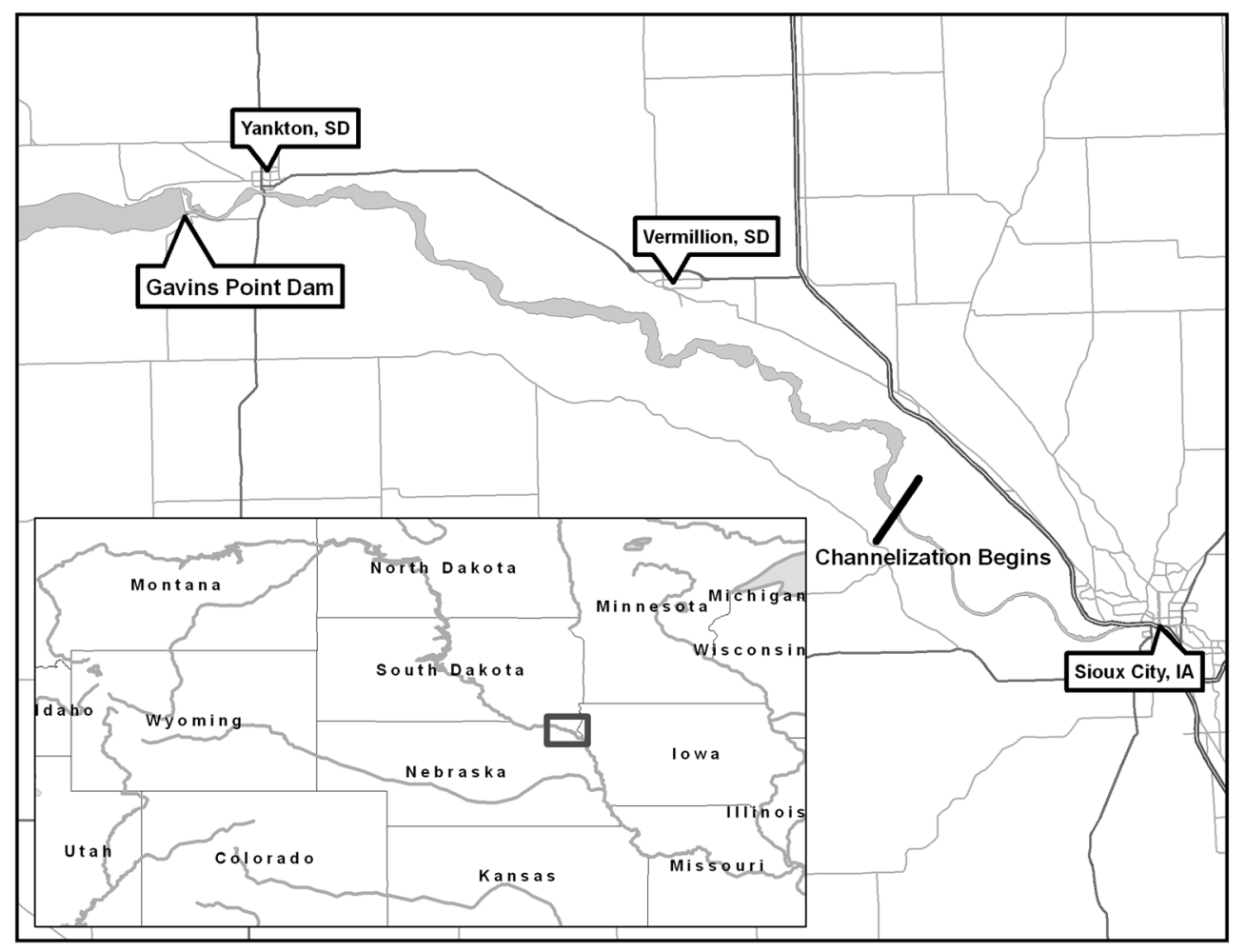

Figure 1. Map of the study area 
through the northern Great Plains and Corn Belt and entering the Mississippi River near St. Louis, Missouri (Galat et al., 2005). The pre-regulation Missouri River was a dynamic river, overflowing its banks and meandering through its floodplain (Schneiders, 1999). Side channels, backwaters and floodplain lakes were formed as the channel shifted laterally across its floodplain. This movement of the channel was influenced by two yearly flood pulses, also known as spring rises. The first, often in April, represented local and regional snow melt and rainfall, whereas the second, in June, represented the snow melt from the Rocky Mountains (Galat et al., 2005; NRC, 2011).

System-wide regulation of the Missouri began with the construction of Fort Peck Dam in Montana in the 1930s, with five other dams and reservoirs completed in the 1950s and 1960s as part of the Pick Sloan Plan of 1944. The MRBSNP of 1945 , along with earlier channelization efforts, led to the channelization of the lower $1178 \mathrm{~km}$ of the Missouri River, with the creation of a uniform navigation channel $2.7 \mathrm{~m}$ deep and $91 \mathrm{~m}$ wide. These two programmes transformed the Missouri River from a natural free-flowing dynamic state to a channelized and impounded river (Schneiders, 1999).

The tail waters of the farthest downstream and smallest of the main stem dams, Gavins Point (completed in 1957), form the most downstream unchannelized segment of river, running from Yankton, South Dakota to Ponca, Nebraska (Figure 1). Under the authority of the Wild and Scenic Rivers Act, this $95-\mathrm{km}$ segment was designated as part of the MNRR (administered by the National Park Service) in 1978 because of its unchannelized nature and historic, scenic and natural qualities. Unlike the channelized river downstream, this segment (known as the 59-mile segment of the MNRR) has a wide and shallow channel with a shifting, meandering current, islands, sandbars and wetland areas (Spegel, 2009). Despite these 'natural' qualities, this segment has suffered species and habitat loss (Schmulbach et al., 1981), channel degradation (WEST Consultants, Inc., 2002; Jacobson et al., 2009) and a greatly altered hydrograph because of flow regulation by upstream dams (Galat and Lipkin, 2000).

\section{Mapping historic change in off-channel habitats}

Scanned, georeferenced aerial photographs from 1941 (US Department of Agriculture), 1983-1985 (NHAP1, US Geological Survey) and 2008 (National Agricultural Imagery Program) were used to map historic changes in off-channel habitats. Black-and-white US Department of Agriculture photography from 1941 was used to characterize the preregulation river (Table I). Fort Peck Dam in Montana (completed in 1937) was the only main stem dam in operation on the river at the time and had little, if any, influence on floods generated from the Great Plains snowmelt
Table I. Dates, location and recorded daily discharge for all aerial imagery. US Geological Survey gauge numbers are provided in parentheses

\begin{tabular}{|c|c|c|c|}
\hline Image Date & $\begin{array}{l}\text { Image location } \\
{\text { (river km })^{\mathrm{a}}}^{\text {Ima }}\end{array}$ & $\begin{array}{c}\begin{array}{c}\text { Discharge } \\
\left(\mathrm{m}^{3} \mathrm{~s}^{-1}\right)\end{array} \\
\text { Yankton, } \\
\text { South Dakota } \\
(06467500)\end{array}$ & $\begin{array}{c}\begin{array}{c}\text { Discharge } \\
\left(\mathrm{m}^{3} \mathrm{~s}^{-1}\right)\end{array} \\
\text { Sioux City, }\end{array}$ \\
\hline $10 / 8 / 1941$ & $1305-1271$ & 583 & 549 \\
\hline $1 / 9 / 1941$ & 1236-1199 & 603 & 643 \\
\hline 7/10/1941 & $1275-1236$ & 575 & 609 \\
\hline $23 / 5 / 1983$ & $1242-1196$ & 725 & 878 \\
\hline 24/10/1984 & $1275-1239$ & 1348 & 1393 \\
\hline $23 / 5 / 1984$ & $1297-1255$ & 663 & 813 \\
\hline $18 / 5 / 1985$ & $1305-1292$ & 810 & 886 \\
\hline $1 / 7 / 2008$ & $1305-1181$ & 368 & 498 \\
\hline $2 / 7 / 2008$ & $1305-1233$ & 283 & 501 \\
\hline $3 / 7 / 2008$ & $1305-1267$ & 283 & 444 \\
\hline $8 / 8 / 2008$ & $1234-1181$ & 623 & 651 \\
\hline
\end{tabular}

${ }^{a}$ Correspond to river km from the mouth of the Missouri.

(the early spring rise) but likely did influence flows from Rocky Mountain snowmelt (the June rise). Colour infrared aerial photography for 1983, 1984 and 1985 was from the NHAP1 project of the US Geological Survey. By the early 1980s, all six main stem dams had been completed and in operation for 20 years or more, with the two immediate upstream dams, Gavins Point and Fort Randall, completed in 1957 and 1953, respectively. Imagery for 2008 was from the National Agricultural Imagery Program. Images were true-colour digital orthorectified county mosaics with a pixel size of $1 \mathrm{~m}$.

Comparisons of backwater and side channel area by date were complicated somewhat by differences in flow between aerial photography dates (Table I). Reservoir levels were at record lows in 2008, with daily flows during the 2008 photograph dates lower than on both the 1980s and the 1941 imagery dates. Flows on 2008 photograph dates averaged 34\% less at Yankton and 13\% less at Sioux City than flows on the 1941 imagery dates. Flows averaged higher on the 1983-1985 photograph dates than in the 1941 and 2008 imagery, by $33 \%$ and 56\%, respectively, at Yankton and $40 \%$ and $47 \%$, respectively, at Sioux City. Flows on one date, 24 October 1984, were substantially higher $\left(1348 \mathrm{~m}^{3} \mathrm{~s}^{-1}\right.$ at Yankton; $1393 \mathrm{~m}^{3} \mathrm{~s}^{-1}$ at Sioux City) than those on the other 1983-1985 imagery dates $\left(663-810 \mathrm{~m}^{3} \mathrm{~s}^{-1}\right.$ at Yankton; $813-886 \mathrm{~m}^{3} \mathrm{~s}^{-1}$ at Sioux City). On the basis of provisional field records, these discharge differences translate into stage differences of $1.3 \mathrm{~m}$ at Yankton and $1.2 \mathrm{~m}$ at Sioux City between the days of highest and lowest discharge during the period. Such differences could impact and possibly inflate estimates of off-channel habitat area and numbers of features for the 1980s images. However, only $11 \mathrm{~km}$ (out of the $95 \mathrm{~km}$ ) of our study reach was covered 
exclusively by imagery taken on this date of exceptionally high flow, with few off-channel features measured on that subreach. Overall, we consider potential influences of flow differences to be minor compared with the magnitude of changes in habitat area observed over the time series, particularly for the 1941 versus 2008 comparisons.

Using historic and recent imagery, we interpreted all recognizable off-channel habitats and digitized them as polygon features in ArcGIS 9.3 (ESRI Inc., Redlands, California), at a scale of 1:10000. Off-channel habitats were defined as 'bodies of water adjacent to the main channel that have surface water connections to the main river channel' (Landers et al., 2002). Only water features were digitized, and these were generally separated from the main channel by adjacent vegetated surfaces or large, relatively stable sandbars. We classified each polygon of off-channel habitat as either a backwater or a side channel and determined the area, perimeter and length (longest axis) of each off-channel feature in each image year. Side channels were flowing offchannel habitats with both an upstream and downstream connection to the main river channel (Landers et al., 2002). Although the two terms are sometimes synonymous, we distinguished between secondary channels and side channels and only mapped the latter. Features defined as side channels were narrower $(<100 \mathrm{~m})$ than the main or secondary channel and received less flow (often with exposed sand) than the main channel (Figure 2). We defined a backwater as a body of water with a downstream connection to the main channel and with little to no upstream connection at normal (nonflood) flows (Figure 2). Other authors have also referred to these bodies of water as 'alcoves' (Landers et al., 2002) or 'backups' (Schmulbach et al., 1981).

We were unable to determine water depth or velocity from recent and historical aerial imagery and hence could not evaluate to what degree our off-channel habitats were synonymous with shallow water habitats, as defined by the US Fish and Wildlife Service (depth $<1.5 \mathrm{~m}$, velocity $<0.6 \mathrm{~m} \mathrm{~s}^{-1}$ ). Shallow water habitats are a focus of mitigation and restoration efforts to restore spawning and nursery areas for rare benthic fish along the lower Missouri (USFWS, 2000, 2003).

\section{Statistical analysis}

We tested for differences in mean characteristics of offchannel habitats (e.g. length, perimeter, area) and river flows between dates using two-sample $t$-tests with unequal variances, using the Microsoft Excel $^{\circledR}$ Analysis ToolPak (Microsoft Corporation, Redmond, Washington). The chi-square test for independence was used to assess changes across dates in the relative numbers of backwaters and side channels. For all statistical tests, we considered $p$-values $\leq 0.05$ to represent strongly significant differences, whereas values between 0.05 and 0.10 were

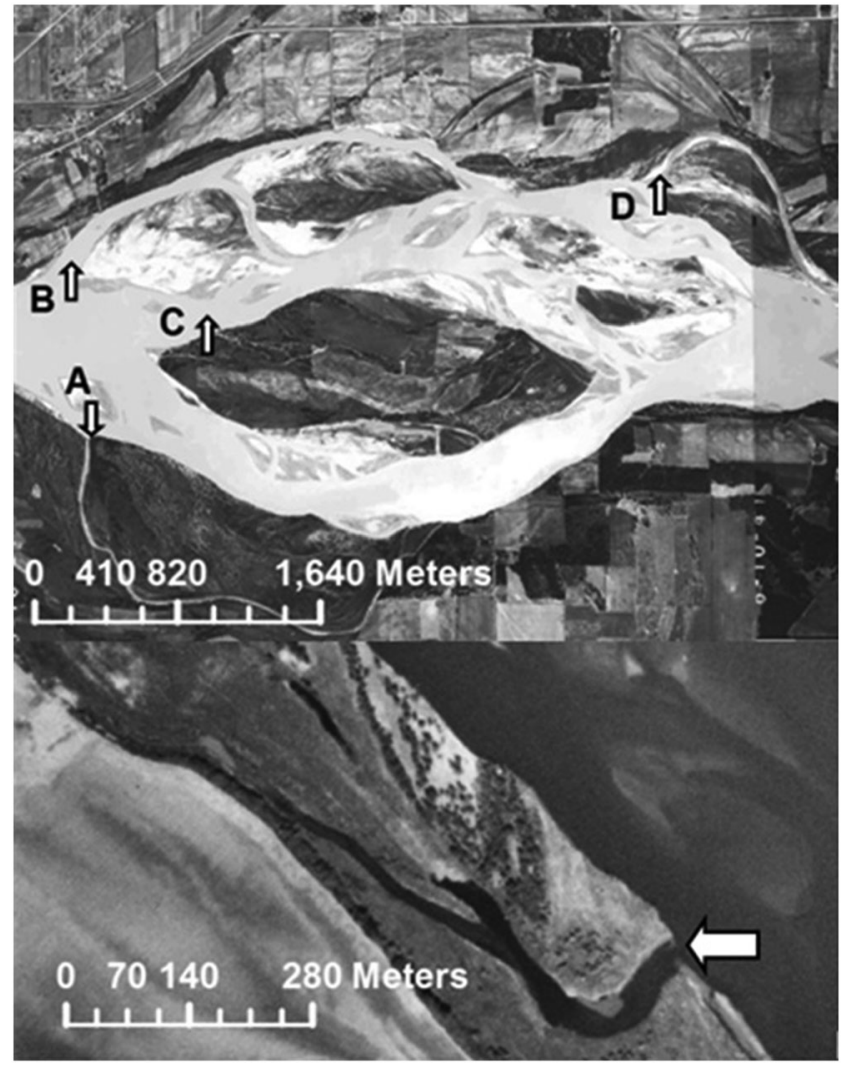

Figure 2. Aerial imagery from 1941 (top) and 1985 (bottom), depicting main channel, secondary channel, side channel and backwater features. In the top image, features ' $A$ ' and ' $D$ ' are side channels. They are narrow $(<100 \mathrm{~m}$ wide), have exposed sand and maintain both upstream and downstream connections to the main channel. Features ' $\mathrm{B}$ ' and ' $\mathrm{C}$ ' are secondary channels. They are wide $(>100 \mathrm{~m})$ and maintain a direct connection to the main channel. The arrow in the bottom image denotes a backwater, characterized by a downstream connection to the main channel but no upstream connection

considered weakly significant. Means are reported with standard errors. All results, unless specifically stated, represent natural off-channel features only as our goal was to assess how changes in fluvial geomorphic processes because of dam operations have influenced development and persistence of off-channel habitats. Data for three human-restored backwaters (constructed 2004-2008) in the study area are shown separately (Table II).

\section{RESULTS}

Total area, length, perimeter and number of natural off-channel habitats (backwaters and side channels) declined through time within the study area (Table II). Total area of off-channel habitats declined by 56\% between 1941 and 1983-1985 and by 32\% from 1983-1985 to 2008, for a net loss of 70\% (65\% if restored backwaters included) over 1941-2008. Total length and perimeter of off-channel 
Table II. Historic changes in the number, length, area and perimeter of off-channel habitats within the study reach

\begin{tabular}{|c|c|c|c|c|c|c|c|c|}
\hline Imagery date & Feature type & Total number & $\begin{array}{l}\text { Total length } \\
\text { (m) }\end{array}$ & $\begin{array}{l}\text { Mean length } \\
\text { (m) }\end{array}$ & $\begin{array}{c}\text { Total area } \\
\text { (ha) }\end{array}$ & $\begin{array}{c}\text { Mean area } \\
\text { (ha) }\end{array}$ & $\begin{array}{l}\text { Total perimeter } \\
\text { (m) }\end{array}$ & $\begin{array}{l}\text { Mean perimeter } \\
\text { (m) }\end{array}$ \\
\hline \multirow[t]{4}{*}{2008} & Restored backwater & 4 & 4723 & $1181(483)$ & 21.2 & $5.3(1.7)$ & 10789 & $2697(986)$ \\
\hline & Natural backwater & 11 & 6874 & $625(121)$ & 31.0 & $2.8(0.7)$ & 18317 & $1665(374)$ \\
\hline & Side channel & 9 & 12567 & 1396 (184) & 80.0 & $8.9(2.4)$ & 30325 & 3369 (407) \\
\hline & $\begin{array}{l}\text { All natural } \\
\text { features }\end{array}$ & 20 & 19441 & $972(136)$ & 111.1 & $5.6(1.3)$ & 48642 & $2432(331)$ \\
\hline \multirow[t]{3}{*}{ 1983-1985 } & Backwater & 15 & 9823 & $655(98)$ & 27.0 & $1.8(0.3)$ & 23853 & $1590(216)$ \\
\hline & Side channel & 20 & 29390 & $1470(356)$ & 135.9 & $6.8(1.9)$ & 74230 & $3711(867)$ \\
\hline & All features & 35 & 39213 & $1120(216)$ & 162.9 & $4.7(1.2)$ & 98083 & $2802(530)$ \\
\hline \multirow[t]{3}{*}{1941} & Backwater & 5 & 3692 & 738 (293) & 22.2 & $4.4(2.8)$ & 8086 & $1617(606)$ \\
\hline & Side channel & 25 & 60033 & $2401(545)$ & 350.5 & $14.0(5.1)$ & 129611 & $5184(1,112)$ \\
\hline & All features & 30 & 63725 & $2124(469)$ & 372.6 & $12.4(4.3)$ & 137698 & $4590(960)$ \\
\hline
\end{tabular}

For means, standard errors are reported in parentheses.

features also declined sharply over 1941-1980s (38\% and $29 \%$, respectively), 1980s-2008 (50\% for both) and cumulatively across the whole time period $(69 \%$ and $65 \%$, respectively; $62 \%$ and $57 \%$ if restored backwaters included). The total number of off-channel features increased slightly from 1941 (30) to 1983-1985 (35) but decreased strongly by $2008(20)$.

Strong shifts in the relative and absolute numbers of natural backwaters and side channels occurred over time (Table II), with a progressive decline in the number of side channel habitats and a shift in the ratio of side channels to backwaters. In 1941, prior to the construction and operation of nearby upstream dams, $83 \%$ ( 25 of 30 ) of the identified off-channel features were side channels. By 1983-1985, the ratio of side channels to backwaters had changed markedly $\left(\chi^{2}=5.202\right.$, d.f. $\left.=1, p=0.023\right)$ as the number of side channels declined (from 25 to 20 ) and the number of backwaters increased (from 5 to 15). The number of side channels and natural backwaters both declined from 1983-1985 to 2008, with particularly strong declines in side channels (from 20 to 9), although shifts in the relative proportion of side channels to backwaters were not significant $\left(\chi^{2}=1.663\right.$, d.f. $\left.=1, p=0.197\right)$. Cumulative changes from 1941-2008 showed a significant shift in the numbers of side channels relative to backwaters $\left(\chi^{2}=8.104\right.$, d.f. $=1$, $p=0.004$ ), with a sharp decline in the number of side channels (from 25 to 9) and an increase in the number of natural backwaters (from 5 to 11 ).

Changes in the total and relative areas of natural side channels and backwaters were similar to the trends observed for feature numbers (Table II). The total area of side channels decreased by $61 \%$ from 1941 to $1983-1985$ and by $41 \%$ from $1983-1985$ to 2008 , for an overall decline of $77 \%$ over 1941-2008. Total area of natural backwaters increased by $22 \%$ from $1941-1980$ s and $15 \%$ from 1980s2008, for a total increase of $40 \%$ from 1941-2008 (135\% if restored backwaters included). The proportion of the total off-channel habitat area comprised of side channels declined from $94 \%$ in 1941 to $83 \%$ in $1983-1985$ and $72 \%$ in 2008 (60\% if restored backwaters included). The mean areas of individual side channels and natural backwaters declined from 1941 to $1983-1985$ (51\%, $p=0.099$ and 59\%, $p=0.056$, respectively) but increased slightly (not significant for side channels) between 1983-1985 and 2008 ( $31 \%, p=0.254$ and $56 \%, p=0.073$, respectively).

Side channel mean length declined significantly $(p=0.046)$ between $1941(2401 \pm 545 \mathrm{~m})$ and $2008(1396 \pm 184 \mathrm{~m})$, with most of the change occurring by 1983-1985 (Table II). Similar changes occurred for mean perimeter, with a $28 \%$ decline from 1941-1980s and a 9\% decline from 1980s-2008, for a $35 \%$ decline from 1941-2008. Total side channel length decreased by $51 \%$ from 1941 to $1983-1985$ and again by 57\% from 1983-1985 to 2008, for an overall decrease of $79 \%$ from 1941 to 2008. Backwater total length nearly tripled from 1941 to the 1980s but decreased by $30 \%$ from the 1980 s to 2008. Despite some declines between the 1980s and 2008, total number, length, perimeter and area of natural backwaters were all higher in 2008 than in 1941, whereas side channel number, length, perimeter and area were greatly reduced.

\section{DISCUSSION}

\section{Impacts of flow regulation on off-channel habitats}

Flow regulation by upstream dams (e.g. Garrison and Fort Randall completed in 1952 and 1953, respectively; Gavins Point in 1957) has dramatically altered both flow and sediment regimes within the 59-mile segment of the MNRR (Galat and Lipkin, 2000; Jacobson et al., 2009; NRC, 2002, 2011), impacting the processes necessary for formation and maintenance of dynamic floodplain and channel features. Mean annual peak flows declined significantly in magnitude at the Sioux City, Iowa gauge (i.e. by 67\%, $t=5.097$, d.f. $=17, \quad p<0.0001)$, from $4477( \pm 570) \mathrm{m}^{3} \mathrm{~s}^{-1}$ over 
1929-1953 to $1471( \pm 64) \mathrm{m}^{3} \mathrm{~s}^{-1}$ over $1954-2010$, with no flows exceeding $3000 \mathrm{~m}^{3} \mathrm{~s}^{-1}$ between 1953 and 2010 (Figure 3). Upstream reservoirs have dramatically reduced sediment loads downstream from Gavins Point Dam, with an estimated $99.8 \%$ decline in sediment loads at Yankton, South Dakota (from 125 to 0.25 metric tonnes/year) (Jacobson et al., 2009). On the basis of a geographic information system analysis of the study reach, Dixon et al. (in review) found reductions in geomorphic dynamism in terms of lateral erosion ( $70 \%$ decline) and accretion rates (27\% decline), a reduction in active channel area of $28 \%$ and an $81 \%$ decline in unvegetated sandbar habitat from 1955-1956 to 2006. Most notably, the near cessation of downstream sediment transport from Gavins Point Dam has contributed to substantial channel bed degradation since the 1950s, with declines in river stage of $3.5 \mathrm{~m}$ directly below the dam (Jacobson et al., 2009) and an average of more than $2 \mathrm{~m}$ throughout the entire reach (Figure 4, WEST Consultants, Inc., 2002). The combination of these factors has led to increasing disconnection of the river channel from the floodplain and from former shallow water and off-channel habitats (Elliott and Jacobson, 2006; NRC, 2011). Flow regulation has largely eliminated large, avulsive flows that formerly formed new side channels or restored old ones, whereas channel bed degradation has further isolated river flows from off-channel habitats, simplified channel structure and drained former wetland and shallow water habitats (NRC, 2011).

Although the study area is not part of the MRBSNP, $33 \%-40 \%$ of the reach has been stabilized (National Park Service, unpublished data) by local landowners and state and federal agencies, including a stabilization demonstration

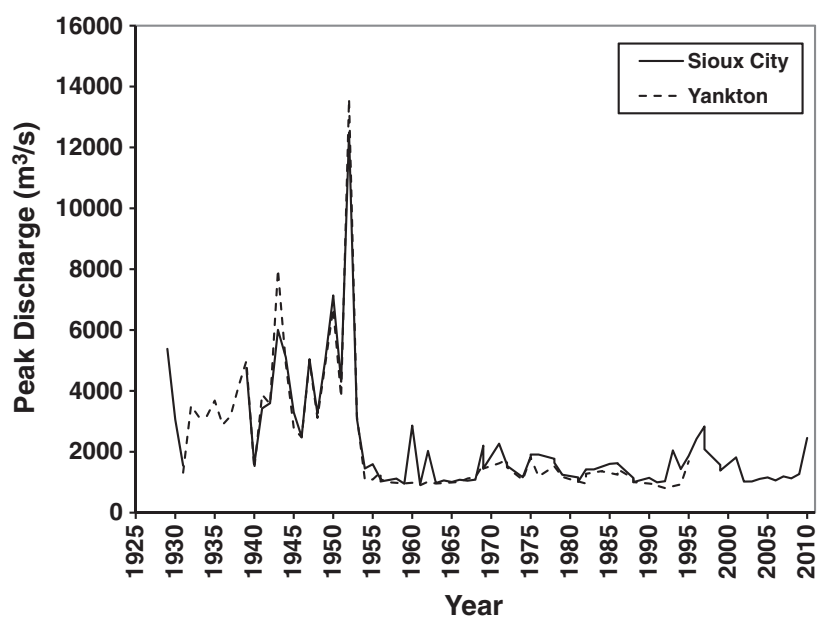

Figure 3. Historic changes in annual peak river discharge on the Missouri River at the Yankton, South Dakota (\#06467500) and Sioux City, Iowa (\#0648600) US Geological Survey gauges. Adjacent upstream dams at Fort Randall and Gavins Point were completed in 1953 and 1957, respectively

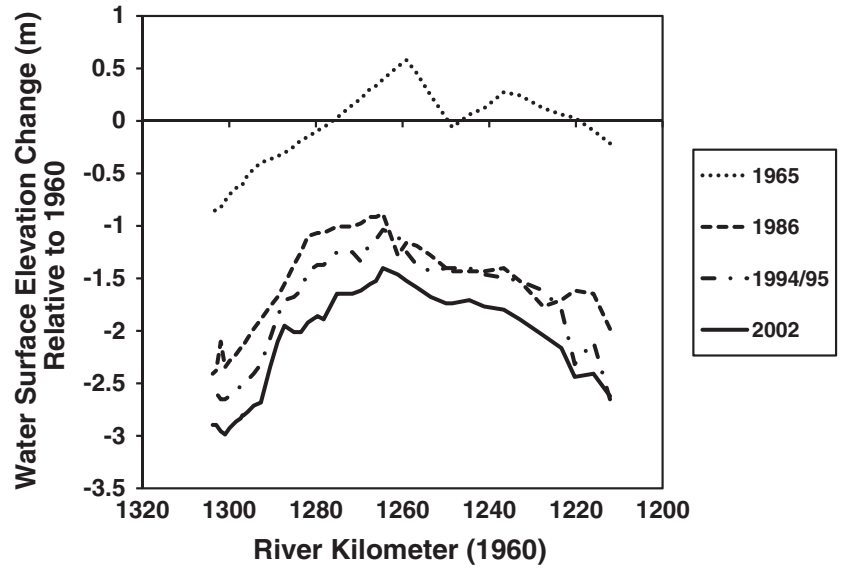

Figure 4. Changes in water surface elevation relative to 1960 for flows at $849.5 \mathrm{~m}^{3} \mathrm{~s}^{-1}$ within the study reach (on the basis of data from WEST Consultants, Inc., 2002)

project by the US Army Corps of Engineers in the late 1970s. Stabilization on the 59-mile segment of the MNRR is composed of individual sites with rock revetments (rip-rap) designed to stop local bank erosion, rather than the system of wing dikes and other structures designed to form and stabilize a reach-wide navigation channel on the lower Missouri. As such, bank stabilization on the study reach has likely had some influence on channel bed degradation and reduced channel migration but has not been a mechanism by which entire backwater or side channel habitats have been cut off from the river channel and eliminated.

Historic changes within our study area suggest a progressive response of off-channel habitats to flow regulation and channel bed degradation (Figure 5), with sharp declines in total and average length, perimeter and area of off-channel features and a decrease in the relative proportion of side channels (Table II). An initial increase in the number of side channels between 1941 and 1983-1985 may reflect conversion of former secondary channels to narrower, shallower side channels as peak flows declined, and the channel bed progressively degraded. Historic declines in the number, size and length of side channels, moderate increases in backwater number and area and an overall increase in the ratio of backwaters to side channels suggest a process of conversion of side channels to backwaters through loss of the upstream channel connection from channel downcutting, sedimentation and vegetation expansion. Although such a process seems logical, direct evidence of side channel to backwater conversions is lacking in our data, perhaps because of habitat changes that are rapid relative to the 23-44 year intervals between photograph dates or to different mechanisms for backwater formation. Instead, the dominant changes that we observed were complete losses of individual off-channel features (side channels or backwaters) between dates, through conversion to terrestrial 


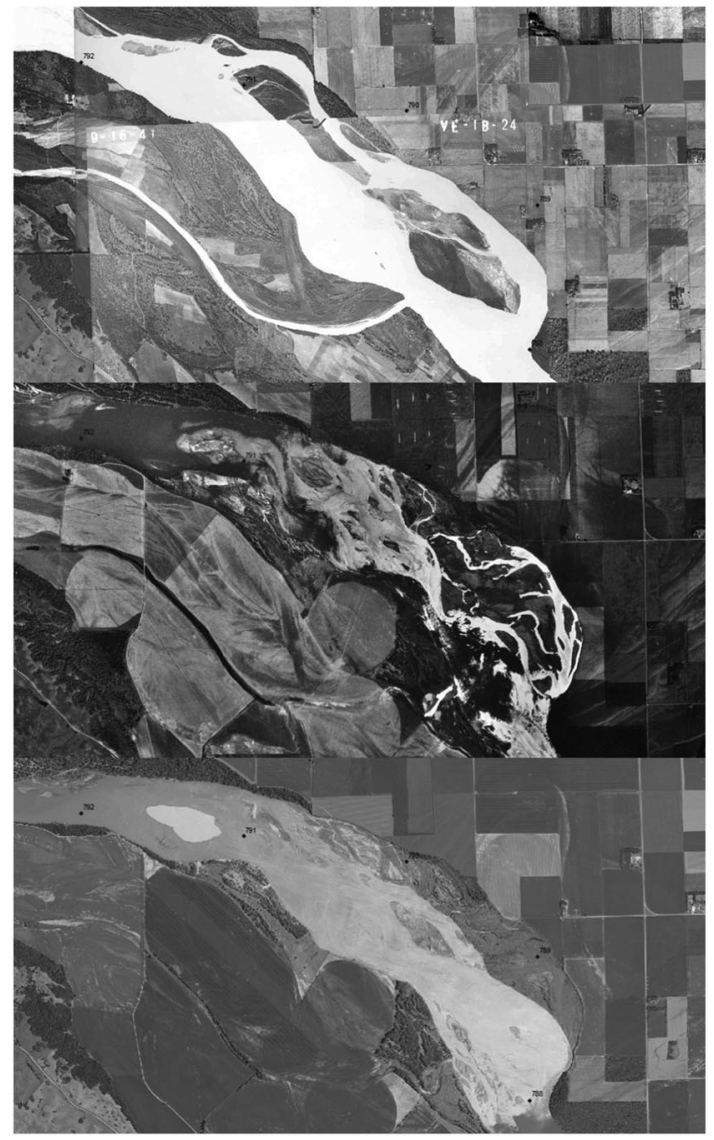

Figure 5. Changes in off-channel habitats are visible from 1941 (top) to 1983-1985 (middle) and 2008 (bottom) for a portion of the study reach (St. Helena Island area, south-east of Yankton, South Dakota)

land cover or, in some cases, to river channel because of shifts in the main channel (Yager and Dixon, personal observation). Analysis of additional, intervening photography dates (and hence shorter time intervals) may be necessary to elucidate the actual sequence of habitat changes that led to net losses in off-channel habitat area, perimeter and length.

Other studies (Morris et al., 1968; Volesky, 1969; Schmulbach et al., 1981; Elliott and Jacobson, 2006) have also estimated areas of off-channel habitats within the study area. Each concluded that the area or number of side channel and backwater habitats has declined, although none took a time series approach to document these changes. Elliott and Jacobson (2006) mapped side channel chutes, defined as secondary channels much narrower than the main or primary channel, from 1941 imagery. Although they used a definition very similar to ours for side channels, Elliott and Jacobson were presumably less inclusive and identified 13 side channel chutes with an average length of $3670 \mathrm{~m}$, $1269 \mathrm{~m}$ longer than the average length that we calculated from the 1941 imagery. Our definition included many shorter side channels, resulting in a smaller average length and a greater number of identified features. Morris et al. (1968) and Volesky (1969) estimated that backwaters (referred to as backups and marshes) alone represented approximately $5 \%$ of the area between high water marks (estimated at 7367 ha by Schmulbach et al., 1981) within the study area in the late 1960s or approximately 368 ha. This estimate is comparable to our estimate of total offchannel habitat for 1941 but is much larger than our estimates from 1983-1985 for backwaters (27 ha) and total off-channel habitat (163 ha) (Table II). Schmulbach et al. (1981) used 1979 aerial photography and ground-truthing to estimate that chutes/side channels constituted 273.78 ha or $3.72 \%$ of the area between the high water mark, whereas backwater habitat (including backups and marshes) was limited to $0.83 \%$ and 61.21 ha. His estimates are approximately two times larger than our 1983-1985 estimates of side channel (136ha) and backwater area. Differences in how off-channel habitats were defined in each study make direct comparisons with our estimates difficult, however. For example, Schmulbach's definition of a chute (or side channel) included any 'subsidiary' channels, generally with depths $<2 \mathrm{~m}$ and a mean current velocity of $<0.75 \mathrm{~m} \mathrm{~s}^{-1}$ (Schmulbach et al., 1981), with parts of the main channel that were in a 'transitory' stage also placed within the chute/side channel habitat.

\section{Management implications}

Efforts to restore or recreate shallow water, off-channel habitats (Hamburg and Burke, 1999; Jacobson et al., 2004a, 2004b; USACE, 2008) on the Missouri River have focused on the lower, channelized river between Sioux City, Iowa and St. Louis, Missouri because of federal mandates to protect the endangered pallid sturgeon (USFWS, 2000, 2003), with little attention to unchannelized segments upstream. Extensive channelization and bank stabilization under the MRBSNP has resulted in the loss of approximately 67987 ha of natural channel, 143258 ha of meander belt and $50 \%$ of the river's surface area on the channelized lower $1178 \mathrm{~km}$ of river. Stabilization has caused nearly $90 \%$ loss of off-channel and shallow water habitats while nearly eliminating sandbars, islands, oxbows and backwaters (Funk and Robinson, 1974; USGS, 1998).

Our findings show that significant losses of off-channel habitats have occurred on an unchannelized upstream segment of the Missouri as well, with particularly steep declines in side channel number, length, perimeter and area. Declines in these habitats have likely led to decreased productivity in the river ecosystem. Nearly $67 \%$ of off-channel benthic insect production was estimated to have been lost in conjunction with channelization on the Missouri River (Morris et al., 1968). Within our study area, Mestl and Hesse (1993) found that secondary production declined 
nearly 61\% between 1963 and 1980. In 1963, off-channel areas provided $37 \%$ of the secondary production; yet, by 1980 , these habitats only contributed $19 \%$. Biomass of insects produced by these habitats also dropped $80 \%$ from 1963 to 1980. This decline in aquatic insects may also have contributed to the loss of native fish species within the Missouri River (Hesse, 1987; Weeks et al., 2005). With continued steep declines in natural off-channel habitats from the 1980 s to present, levels of productivity have likely continued to decline as well.

Some restoration or recreation of backwater habitats has occurred recently on the 59-mile MNRR, with three backwaters created or restored between 2004 and 2008 (Yager, 2010). These backwaters were constructed in conjunction with excavation of sediment to create sandbar nesting habitat for two threatened and endangered birds, Interior Least Tern (Sternula antillarum athalassos) and Piping Plover (Charadrius melodus), as part of the Emergent Sandbar Habitat programme of the US Army Corps of Engineers (USFWS, 2003; USACE, 2011; NRC, 2011). These new backwaters have, at least in part, helped to counteract some of the losses of natural off-channel habitats, although historic losses have been primarily of side channels. Initial monitoring suggests that these recreated habitats are being used by a diversity of fish species (Stukel et al., 2009, 2010) and are showing evidence of other off-channel habitat characteristics and functions (Yager, 2010). These findings, in combination with the historic losses of off-channel habitats documented in our study, suggest that mandates for off-channel habitat restoration should be expanded to include upstream, unchannelized reaches such as the 59-mile segment of the MNRR. In addition, given the disproportionately greater losses of side channels in comparison to backwaters, we recommend that future efforts prioritize side channel restoration.

\section{ACKNOWLEDGEMENTS}

Funding for this research was provided by the Missouri River Institute and the University of South Dakota and formed the basis for the MS thesis work of Lisa Yager.

\section{REFERENCES}

Angradi TR, Schweiger EW, Bolgrien DW. 2006. Inter-habitat variation in the benthos of the upper Missouri River (North Dakota, USA): implications for Great River bioassessment. River Research and Applications 22: 755-773.

Bayley PB. 1995. Understanding large river-floodplain ecosystems. BioScience 45: 153-158.

Dixon MD, Johnson WC, Scott ML, Bowen D, Rabbe LA. In review. Dynamics of plains cottonwood (Populus deltoides) forests and historic landscape change across the upper Missouri River, USA. Environmental Management.
Elliott CM, Jacobson RB. 2006. Geomorphic Classification and Assessment of Channel Dynamics in the Missouri National Recreational River, South Dakota and Nebraska. U.S. Geological Survey, Scientific Investigations Report 2006-5313; 66.

Funk JI, Robinson JW. 1974. Changes in the Channel of the Lower Missouri River. Aquatic Series No. 11. Missouri Department of Conservation: Jefferson City, MO.

Galat DL, Lipkin R. 2000. Restoring ecological integrity of great rivers: historical hydrographs aid in reference conditions for the Missouri River. Hydrobiologia 422/423: 29-48.

Galat DL, Berry CR, Gardner WM, Henrickson JC, Mestl GE, Power GJ, Stone C, Winston MR. 2005. Spatiotemporal patterns and changes in Missouri River fishes. American Fisheries Society Symposium 45: 249-291.

Gergel SE, Dixon MD, Turner MG. 2002. Consequences of human-altered floods: levees, floods, and floodplain forests along the Wisconsin River. Ecological Applications 12(6): 1755-1770.

Hamburg DD, Burke VJ. 1999. Initial Biotic Survey of Lisbon Bottom, Big Muddy National Fish and Wildlife Refuge. Biological Science Report USGS/BRD/BSR-2000-0001.

Hesse LW. 1987. Taming the wild Missouri: what has it cost? Fisheries 12: 2-9.

Jacobson RB, Johnson HE, Laustrup MS, D'Urso GJ, Reuter JM. 2004a. Physical Habitat Dynamics in Four Side-Channel Chutes, Lower Missouri River. USGS Open-file Report 2004-1071.

Jacobson RB, Elliott CM, Johnson HE III. 2004b. Assessment of ShallowWater Habitat Availability in Modified Dike Structures, Lower Missouri River. USGS Open-File Report 2004-1409.

Jacobson RB, Blevins DW, Bitner CJ. 2009. Sediment regime constraints on river restoration-an example from the Lower Missouri River. In Management and Restoration of Fluvial Systems with Broad Historical Changes and Human Impacts, James LA, Rathburn SL, Whittcar GR (eds). Geological Society of America Special Paper 451; 1-22.

Junk WJ, Bayley PB, Sparks RE. 1989. The flood pulse concept in riverfloodplain systems. Canadian Special Publication of Fisheries and Aquatic Sciences 106: 110-127.

Landers D, Fernald A, Andrus C. 2002. Off-channel habitats. In Willamette River Basin Planning Atlas: Trajectories of Environmental and Ecological Change, Hulse D, Gregory S, Baker J. (eds), for the Pacific Northwest Ecosystem Research Consortium, Oregon State University Press: Corvallis, OR; 26-27.

Ligon FK, Dietrich WE, Trush WJ. 1995. Downstream ecological effects of dams: a geomorphic perspective. BioScience 45(3): 183-192.

Mestl G, Hesse L. 1993. Secondary production of aquatic insects in the unchannelized Missouri River. In Proceedings of the Symposium on Restoration Planning for Rivers of the Mississippi River Ecosystem, Hesse LW, Stalnaker CB, Benson NG, Zuboy JR (eds). Biological Report 19. U.S. Department of the Interior National Biological Survey: Washington, DC; 341-349.

Morris LA, Langemeier RN, Russell TR, Witt A Jr. 1968. Effects of Main Stem Impoundments and Channelization upon the Limnology of the Missouri River, Nebraska. Nebraska Game and Parks Commission-Staff Research Publications: Lincoln, NE.

National Research Council (NRC). 2002. The Missouri River Ecosystem: Exploring the Prospects for Recovery. National Academy Press: Washington, D.C.

National Research Council (NRC). 2011. Missouri River Planning: Recognizing and Incorporating Sediment Management. National Academy Press: Washington, D.C.

Nilsson C, Reidy CA, Dynesius M, Revenga C. 2005. Fragmentation and flow regulation of the world's large river systems. Science 308: 5720 . 
Price KH, Townsend SL. 2004. Dealing with Change: Recreating Missouri River backwater habitat. World Water Congress 2004.

Schmulbach JC, Schuckman JJ, Nelson EA. 1981. Aquatic Habitat Inventory of the Missouri River from Gavins Point Dam to Ponca State Park, Nebraska. Job Completion Report. Contract\# DACW45-80C-0155.

Schmulbach JC, Hesse LW, Bush JE. 1992. The Missouri River-Great Plains thread of life. Pages 137-158. In Water Quality in North American River Systems, Becker CD, Nietzel DA (eds). Batelle Press: Columbus, OH.

Schneiders RK. 1999. Unruly River: Two Centuries of Change along the Missouri. University Press of Kansas: Lawrence, KS.

Sheaffer WA, Nickum JG. 1986a. Backwater areas as nursery habitats for fishes in Pool 13 of the Upper Mississippi River. Hydrobiologia 136: $131-140$.

Sheaffer WA, Nickum JG. 1986b. Relative abundance of macroinvertebrates found in habitats associated with backwater area confluences in Pool 13 of the Upper Mississippi River. Hydrobiologia 136: 113-120.

Shields FD Jr, Simon A, Steffen LJ. 2000. Reservoir effects on downstream river channel migration. Environmental Conservation 27(1): 54-66.

Sparks RE. 1995. Need for ecosystem management of large rivers and their floodplains. BioScience 45: 168-182.

Spegel DD. 2009. The Missouri National Recreational River: an unlikely alliance of landowners and conservationists. Nebraska History 90: $22-41$.

Stukel S, Kral J, LaBay S. 2009. Monitoring the Fish Community of an Engineered Backwater of the Missouri River. South Dakota Department of Game, Fish, and Parks. Prepared for U.S Fish and Wildlife Service (Grant Number: E-12-R).

Stukel S, Kral J, LaBay S. 2010. Monitoring the Fish Community of an Engineered Backwater of the Missouri River. South Dakota Department of Game, Fish, and Parks. Prepared for U.S Fish and Wildlife Service (Grant Number: E-12-R).

US Army Corps of Engineers (USACE). 2008. Draft Boyer Chute Backwater and Chute Restoration. Missouri River Fish and Wildlife Recovery Project: Washington County, Nebraska.

US Army Corps of Engineers (USACE). 2011. Final Programmatic Environmental Impact Statement for the Mechanical and Artificial Creation and Maintenance of Emergent Sandbar Habitat in the Riverine Segments of the Upper Missouri River. US Army Corps of Engineers: Omaha District, Omaha, NE.

US Fish and Wildlife Service (USFWS). 2000. Biological Opinion of the Missouri River Main Stem Reservoir System, Operation and Maintenance of the Missouri River Bank Stabilization and Navigation Project, and Operation of the Kansas River Reservoir System. U.S. Fish and Wildlife Service, Region 6: Denver, Colorado and Region 3: Fort Snelling, Minnesota; 286.

US Fish and Wildlife Service (USFWS). 2003. Amendment to The 2000 Biological Opinion on the Operation of the Missouri River Main Stem Reservoir System, Operation and Maintenance of the Missouri River Bank Stabilization and Navigation Project, and Operation of the Kansas River Reservoir System. U.S. Fish and Wildlife Service: Minneapolis, MN, USA; 298.

US Geological Survey (USGS). 1998. Lower Missouri River Ecosystem Initiative Final Report. US Geological Survey Columbia Environmental Research Center: Columbia, Missouri; 20.

Volesky DF. 1969. A Comparison of the Macrobenthos from Selected Habitats in Cattail Marshes of the Missouri River, Vermillion, SD, MA Thesis, University of South Dakota, Vermillion, SD.

Ward JV, Stanford JA. 1995. Ecological connectivity in alluvial river ecosystems and its disruption by flow regulation. Regulated Rivers: Research \& Management 11: 105-119.

Weeks DP, Vana-Miller DL, Pranger H. 2005. Missouri National Recreational River. Water Resources Information and Issues Overview Report. Technical Report NPS/NRWRD/NRTR-2005/326.

WEST Consultants, Inc. 2002. Missouri River Gavins Point Dam Degradation Trends Study. Prepared for US Army Corps of Engineers, Omaha District, Contract DACW 45-01-D-003, Task order \#0013.

Whitley JR, Campbell RS. 1974. Some aspects of water quality and biology of the Missouri River. Transactions, Missouri Academy of Science 7/8: 60-72.

Yager LA. 2010. Historic Changes and Water Quality Characteristics of Off-Channel Habitats on the 59-Mile Segment of the Missouri National Recreational River (MNRR). MS Thesis, Department of Biology, University of South Dakota, Vermillion, SD. 